\title{
THE LANGUAGES WITHOUT BORDERS PROGRAM AS A TEACHER EDUCATION POLICY IN BRAZIL
}

O Programa Idioma sem Fronteiras como política de educação do professor no

\section{Brasil}

\section{Anamaria Kurtz de Souza WELP* Álvaro Rutkoski DIDIO**}

\begin{abstract}
This article aims to present part of an investigation conducted in the Language Center of the Languages Without Borders Program (LwB) of an important public university in the south of Brazil. The research had the objective of analyzing the narratives produced by three English teachers linked to the LwB, starting from the following question: What factors most contributed to your professional development within the LwB context? For the generation of the data, semi-structured interviews were conducted through which the three teachers were encouraged to produce narratives about their education in the LwB context. The results of the analysis of the teachers' accounts suggest that pre-service teachers should prepare themselves for selfreflection and self-analysis, as it is impracticable to separate personal and professional dimensions. The narratives also point to the importance programs such as $\mathrm{LwB}$, which put pre-service teachers in the classroom during their undergraduate years so that their professional development is based on concrete case discussions that aim at articulating theory and practice..
\end{abstract}

KEYWORDS: Teacher education; Internationalization; Languages without Borders
RESUMO: Este artigo tem o propósito de relatar parte de uma investigação conduzida no Núcleo de línguas do Programa Idiomas sem Fronteiras (IsF) de uma importante universidade pública do sul do Brasil. A investigação teve o objetivo de analisar as narrativas produzidas por três professores de inglês vinculados ao IsF, partindose da seguinte pergunta: Quais fatores mais contribuíram para sua formação dentro do IsF? Para a geração de dados, foram feitas entrevistas semiestruturadas através das quais os professores colaboradores eram encorajados a produzir narrativas sobre sua formação no contexto do IsF. Os resultados da análise dos relatos sugerem que os professores em formação devem se preparar para um trabalho sobre si próprios, , de autorreflexão e de autoanálise, pois é impraticável separar dimensões pessoais e profissionais. As narrativas também apontam para a importância de programas de formação como o IsF, que coloquem o professor em pré-serviço já em sala de aula durante seus anos de graduação para que seu desenvolvimento profissional seja embasado em discussões de casos concretos nas quais haja uma articulação entre a teoria e a prática.

PALAVRAS-CHAVE: Formação de Professores; Internacionalização; Idiomas sem Fronteiras

\section{Introduction}

As an effort to boost the internationalization of higher education institutions, in 2013 the Brazilian government launched the Languages without Borders Program $(\mathrm{LwB})^{1}$. One of the major benefits thee $\mathrm{LwB}$ brought in its tail was the investment in

\footnotetext{
* Professor in the Languages and Literature program at the Federal University of Rio Grande do Sul.

*** Undergraduate student of the Languages and Literature program at the Federal University of Rio Grande do Sul.

${ }^{1}$ For more information: http://isf.mec.gov.br/
} 
language teacher education, given that the program works as a residence ${ }^{2}$ in which preservice teachers have the opportunity to articulate pedagogical practice and the theories studied in their undergraduate and graduate programs.

In this context, this article presents a part of the findings from an investigation aimed at observing the impacts of the program on the development of three pre-service English as an Additional Language teachers from the LwB Language Center of a highranked federal free-tuition university in southern Brazil. Through semi-structured interviews, the three teachers constructed narratives and reflected on their acting in the program while answering the following question: what factors most contributed to your professional development in the LwB context? Their accounts were analyzed in light of Nóvoa's perspective concerning teacher education.

\section{A profession built within pedagogical practice and along human development}

Nóvoa (2007 and 2009) believes that in recent years debates on education have brought teachers to the center of concerns and into educational policies discussions. At the beginning of the 21st century, teachers appear as essential and indispensable elements for the promotion of learning and for the construction of inclusive processes to face the challenges of diversity, the development of better methods, and the use of technologies.

As to inspire a renewal in teacher education programs and actions, the author proposes five key dispositions that define contemporary teaching practices: knowledge, professional culture, pedagogical tact, teamwork, and social commitment.

Knowledge refers to knowing those we teach and what we teach and providing opportunities for learning, that is, teachers' work consists of building practices that lead students to learn. Professional culture is created in school routine, in reflection on work, in exchange with the most experienced co-workers, in the exercise of evaluation, and in the register of practices. These are aspects that allow us to learn and advance in the profession. Pedagogical tact refers to the development of the ability to communicate and to win students for school work, i.e., to know how to guide students through learning; something that goes beyond the professional dimension and involves

\footnotetext{
${ }^{2}$ Nóvoa refers to physicians practice-based initial education pointing the need to use a similar model for pre-service teachers. See Nóvoa (2009, p. 6).
} 
the personal one. Teamwork involves organization of professional practices in schools around "communities of practice" ${ }^{3}$, joint intervention in educational projects, collectiveness, and collaboration. Social commitment is shown by principles, values, social inclusion, and cultural diversity: "To educate is to get the child to go beyond the boundaries that, so many times, were traced to them by destiny, by birth, by family or by society" (p. 31). ${ }^{4}$

In addition, Nóvoa believes that, at the present moment, there is a need to think about teacher education considering a connection between teachers' identity and personal dimensions. For him, teachers are formed within the profession and, to construct more appropriate educational proposals, he presents five propositions that constitute the core question and that should be the starting point for action: practice, profession, person, shared work, and public. (p.32).

P1 - Practice: "teacher education should have a strong praxis component, focused on students' learning and on concrete cases, having school work as a reference." ${ }^{5}$ It is necessary to reverse the long tradition of teacher education guided by references which are external to the profession and to establish teaching practices as a place of reflection and development to be transformed into knowledge.

P2 - Profession: "teacher education must happen 'inside' the profession, i.e., it must be based on the acquisition of a professional culture, assigning the more experienced teachers a central role in the formation of the less experienced ones."6 Groups outside the teaching profession have taken the responsibility for teacher education, and for regulating the profession, relegating teachers themselves to a secondary role. Teacher education involves a complexity that can only be obtained through integration of these professionals within such professional culture.

P3 - Person: "teacher education should give special attention to the personal dimension of the teaching profession, working on the relationship and communication

\footnotetext{
3 "Communities of practice are groups of people who share a concern or a passion for something they do and learn how to do it better as they interact regularly." (WENGER, 2015, p.1)

4 "Educar é conseguir que a criança ultrapasse as fronteiras que, tantas vezes, the foram traçadas como destino pelo nascimento, pela família ou pela sociedade.” (p.31)

5 "A formação de professores deve assumir uma forte componente práxica, centrada na aprendizagem dos alunos e no estudo de casos concretos, tendo como referência o trabalho escolar." (p.32)

6 "A formação de professores deve passar para "dentro" da pro fissão, isto é, deve basear-se na aquisição de uma cultura profissional, concedendo aos professores mais experientes um papel central na formação dos mais jovens." (p.36)
} 
capacities that define the pedagogical tact."7 The difficulties pointed out in schools by new social and cultural realities require teachers to be whole people. In this context, it is essential to encourage future teachers to practice self-development through their personal and professional life stories, so that they can better understand their paths.

P4 - Shared work: "teacher education must value teamwork and the collective exercise of the profession, which reinforces the importance of school educational projects." ${ }^{8}$ It is important to build professional ethics in dialogue with other colleagues in a context where dilemmas are marked by cultural differences and value conflicts.

P5 - Public: "Teacher education must be marked by a principle of social responsibility, promoting communication and professional participation in the public sphere of education." ${ }^{9}$ In contemporary times, the prestige of this profession is in its visibility, but there is an absence of teachers' voices in public debates about education. It is essential that teachers know how to win their voice in society and participate in the decisions that are made about school. This is a key issue for the survival of the profession, which depends both on the quality of the work done in schools and on participation and intervention in public spaces of education.

\section{Construction of teachers' identity}

Freire (2001), referring to the human aspect of the teaching profession, reinforces the idea that much in the professional journey is focused on courses taken, on academic development, and on professional experiences. He claims that our presence in the world, our desires and our dreams, i.e., our humanity, are often taken for granted, as if our personal aspects were detached from the professional ones.

In this regard, Rivas et al. (2014) state that we can either see educational practice focusing on the context, or we can observe it by turning our eyes to the subject within that context. Indeed, it is in pedagogical practices, in the relationship with students, with colleagues, with the school community in general, that our identity is

\footnotetext{
7 "A formação de professores deve dedicar uma atenção especial às dimensõ es pessoais da profíssão docente, trabalhando essa capacidade de relação e de comunicação que define o tacto pedagógico." (p.38) 8 "A formação de professores deve valorizar o trabalho em equipa e o exercício colectivo da profissão , reforçando a importância dos projectos educativos de escola." (p.40)

9 "A formação de professores deve estar marcada por um princípio de responsabilidade social favorecendo a comunicação pública e a participação profissional no espaço público da educação." (p.42)
} 
mostly (re)forged, and that our humanity emerges. We are products of the social, political, and cultural environment in which we operate.

According to Nóvoa, it is impossible to separate teachers' personal and professional dimensions. For him, "we teach what we are and (...) in what we are, we find much of what we teach" (Nóvoa, 2009: 38) ${ }^{10}$. The author also emphasizes that teachers should be prepared for self-reflection and self-analysis on their development as professionals and as human beings.

\section{Narratives as a means of self-reflection}

Elliott (2011) explains that conventionally there are two ways to study the social world: one that implies a set of questions asked to a large number of individuals whose answers are quantitatively treated and interpreted; and another that bases investigation on a less structured set of questions whose answers are qualitatively considered. Both methods can be combined to have more thorough analyses and to provide rich textual or observational data. The author suggests, however, that qualitative research generates more comprehensive or fine-grained information. This may be because qualitative researchers are interested in understanding the social world rather than predicting or controlling it (PINNEGAR \& DAYNES, 2012, p. 3). As an alternative to the rigidity of structured quantitavively interpreted interviews, which can "artificially fragment individuals' experiences", Elliott (2011, p. 2) states that the interest in narrative evidence has remarkably grown in the social sciences in the last two decades.

Connelly and Clandinin (2006, p. 477) define narrative inquiry as "the study of experience as story". Inspired by Dewey's notions of learning from experience, the authors were the first to use the term in the field of education (CLANDININ, PUSHOR, and ORR, 2007; DEWEY, 1938). In this context, Brockmeier (2000) believes that we use a wide range of linguistic resources not only to express the temporal dimension of our experiences but also to shape them. As a universal phenomenon, language not only represents reality, but also creates it; not only reflects experience but also brings it into existence. For the author, it is in many forms in oral and written discourse that we order our experiences, memories, intentions, hopes, desires, fears, and concerns.

\footnotetext{
10 "ensinamos aquilo que somos e (...) naquilo que somos, se encontra muito daquilo que ensinamos."
} 
In addition, our stories are loaded with social, political, cultural values. When we produce them, we reflect on them and place ourselves in our reality. Thus, we become aware of our subjectivity. The narrative leads us to the possibility of reality transformation, to the construction of the different aspects of our actions as individuals and of our practices as professionals.

Brockmeier (2000) states that we can construct our narratives according to different models. The choice is very individual and depends on the genre in which we produce them. To study how people make use of these models in their autobiographical accounts is to investigate how we immerse ourselves in the fabric of culture and, at the same time, express our unique individuality.

Our choice of narrative research is also made because we work with people, and therefore, full of subjectivity and uniqueness. As Sancho \& Hernández (2013, p. 343) claim, we try to "show our subjectivity embodied in the unique moment of our meetings. When we talk to or interview someone, we essentially get into a relationship." The authors present some characteristics of the research through bibliographical narratives: this type of investigation places the subject at the center of the research, the constructed knowledge is derived from the experience, and the methodology allows to explore the relationship between the subject and their social, cultural, economic and political context.

\section{The Languages and Literature Program and the LwB Program at the investigated university}

By the time the investigation took place, the Language Center in which the interviewed teachers acted was composed of four coordinators, twenty teachers ${ }^{11}$, six administrative assistants, and four English Teaching Assistants (ETAs) ${ }^{12}$. Among the different activities performed by the coordinators, one of the most important was teacher education sessions. The teachers, undergraduate and graduate students of the Languages and Literature Teaching Program, weekly attended three-hour-long meetings focusing on their education.

\footnotetext{
11 To apply for a teaching grant at the LwB, the Ministry of Education requires that the applicant is undertaking or has a degree in Language Teacher Education.

12 For more information: https://us.fulbrightonline.org/applicants/application-checklists/eta-applicationchecklist
} 
Three of those teachers were invited to this research and became participants in the interviews. To preserve their identities, the following aliases were given to them: Antônia, Francisca, and Carlos. The selection criterion was the following: they should be at the end of or having finished their period of contribution to the program ${ }^{13}$.

Antônia had already finished her undergraduate studies, had not had teaching experience before and was 23 years of age at the time. Francisca was in the sixth semester of her undergraduate studies, had had teaching experience before LwB and was 24 years of age at the time. Finally, Carlos, who was also in the sixth semester of his undergraduate studies, had already had teaching experiences before joining the program and was 28 years of age at the time.

\section{The Generation and Analysis of the Narratives}

To generate the narratives, semi-structured interviews were conducted given their dialogic nature. For Mason (2002), this type of interviews consists of data generation methods which are both flexible and sensitive to the context in which they are produced. They aim at guiding the narratives, but at the same time leaving space for the participants to create their accounts based on their personal and professional experiences. Below, for the analysis, excerpts of the most representative passages of the narratives ${ }^{14}$ produced were selected and interpreted considering the theoretical framework.

\subsection{What factors most contributed to your professional development in the LwB context?}

\section{Antônia}

I think that the praxis. It's the first thing that... most influenced me because if we don't go into the classroom, we don't know what is going to happen. So... like: only by going into the classroom to know what you are going to face.

Also, the contact with the colleagues. I think that this exchange of ideas and, even if they are simple things, like: "what activities can I do in class about this?" or "I don't

\footnotetext{
${ }^{13}$ Being two years the maximum time allowed for this grant to enable other students to have the same opportunity.

${ }^{14}$ Originals in Portuguese can be found at https://goo.gl/RU3MuS
} 
know where to find material", anyway... any conversation, I think it just helps, too. So, the conversations among teachers...

The contact with students, because it's with them that we assemble and build knowledge, anyway.

And also, the meetings with the coordinators. Even if they are administrative, I think that it helps us to have ideas on how the school is formed, or, anyway, a language course.

(...) because it is not only the classroom that matters. If you go teach at a school, you have to have all the administrative issue, you have to keep record of the class record book, you have to prepare classes, you have to deal with parents or families or systems, anyway.

\section{Francisca}

I think that this opportunity of... precisely this, like, of giving you the opportunity of going into a classroom despite your curriculum, you know. I think that it is basically it.

I think that being able to work with undergraduate students, too. I like this very much. I think this profession is one that attracts me the most because it gives me the opportunity to meet people in a non-corporate context, you see? So, I get to know people as people. When you know the student... this is a very humanistic point of view: you see the student as a person, as an individual indeed. And having had this opportunity to have students from the Engineering, from the Physics, from the Biochemistry Programs, which are very distant areas from my own, like, it made me break many stereotypes, made me think a lot about my role as a teacher, as in how to become closer to students, as in approach, like many things, like...

I think that this opportunity to be in the same university that you are having classes in the undergraduate courses and that you are having all this theory, right? In the courses of the Teacher Education Program, at the same time you are having the opportunity to teach, right? So it brings together this thing of... The praxis happens, as Freire said, right? Theory and practice together... You have this possibility, this is very nice, like...

I think that this policy is amazing because I get like... It gets on my nerves the Languages and Literature Program curriculum. It's too theoretical, you see? There is 
very little practice. And I think that when you want a Teacher Education Program, you have to go into the classroom ever since the first term. If I could build my own Languages and Literature program curriculum, [in] the first term there would be practice there. Even if it is just [class] observation, practicum, analysis, whatever it is. [...] First term: you already teach, you already see what awaits you, what this is. Because it is only in the last terms [that we have] those compulsory practica... No! Then you don't even have time to go back [in your career choice] if that is not what you want.

\section{Carlos}

The main factor... was that I came from a model very much based on the textbook, like, only the textbook. And, here, we have a very big freedom with the textbook and with the choice of the activities. Anyway, with didactics, in a general way, like. So, kind of, this to me was always the strongest [aspect of the program]. Actually, it was through the Languages without Borders that I really learned how to teach, without depending on the book, without having to follow a straight step-by-step, like.

Not to mention certain freedoms in other.... For example, other types of courses that we had to teach, that I had never taught, never had this idea of how I could teach. For example, a course on oral presentations, a course on TOEFL, a course on IELTS, those are courses I had never thought of [teaching].

Practice seems to be a key component that appears in the accounts of two of the teachers. Both Antônia and Francisca mention this element as primary to their development in the LwB context. On the one hand, Antônia highlights the understanding of the unpredictability of the classroom; on the other hand, Francisca points out the importance of being in classroom, despite not having teaching experience, unfolding the teacher education nature of the program. The balance between theory and practice is also an aspect emphasized in Francisca's discourse, as well as the development of a critical view of her undergraduate program, which focuses too much on theory, not providing enough chances for students to have contact with praxis.

These statements are aligned with Nóvoa's first propositions, (P1), especially in what concerns learning from concrete cases and having school work as a reference. Knowledge, one of the dispositions a teacher must have according to the author, can 
also be mentioned in regard to Antônia's account when she acknowledges the importance of the contact with the students. This may be relatable to knowing whom we teach because it is the classroom interaction between student and teacher that allows the construction of knowledge. In this sense, one of the greatest contributions of the LwB program is that it has provided, among other things, opportunities for articulating theory and practice, reflecting on classroom experiences perceived by the teachers, and resulting on professional development.

From that, we are led to Nóvoa's second proposition, the creation of a Professional Culture (P2), especially found in Antônia's accounts. She emphasizes that it is not only the classroom environment that is relevant to the profession: in her view, all the administrative part of the school, as well as all the dealing with systems and families, constitute the profession as much as teaching, or the classroom environment. And all these other factors, observable through practice, are transformed into knowledge when one is experiencing the profession with all that it implies, creating then the Professional Culture.

Moreover, Francisca dedicates part of her account to how much she has grown as a person and a professional during the time she has been in the LwB program, evidencing the third proposition, (P3). She explains that, because of the program which is situated in a public free-tuition context -, she had the chance to meet, in her own words, people as people, that is, in a non-corporate environment, where she would have to "dance to their tune". This provided her with the opportunity to develop her pedagogical tact, which focuses on good communication with students, breaking stereotypes of students who are part of programs whose areas are very distant from her own. As a result, not only she developed her personal side, but also the professional one: this specific setting allowed her to rethink her role as a teacher, as in how she will approach students differently now, become closer to them, more open to cultural and academic diversity.

The notion of Shared Work (P4), as Nóvoa puts it, is present in the discourse of one of the teachers: two passages of Antônia's account give evidence to that. First, when she mentions the contact with her colleagues and the conversations among teachers. Second, when she brings up the meetings with the coordinators. In these moments, the idea of "communities of practice" reinforces one of shared experiences 
with colleagues, which lead to learning together and growing together, as people and as professionals. The dialogues built in the interaction with colleagues and with coordinators unveil a partnership that can only be experienced by people who share practices and stories in certain contexts.

Yet, although Antônia describes these interactions - such as asking for materials and suggestions of activities to do in the classroom - as 'simple', they show in fact complex episodes that result in great opportunities for learning about the professional practice from peers. These interactions reflect the construction of a professional culture which emerges from the exchange with the most experienced co-workers and with the creation of school routine, mentioned by Nóvoa.

In addition, Carlos unveils a growth in his professional abilities. His discourse suggests that his experience in the program provided him with confidence to decide, and to deliberate in the classroom, not feeling stuck to the book's step-by-step. Also, he reports that the program broadened his teaching practices and enabled him to expand the repertoire of strategies he had until that point by experimenting with different ways of teaching and freedom to use other resources.

Francisca expressed a perception about the curriculum of the English Teacher Education program being too theoretical. Her perspective concerning this issue probably became stronger with her experience in the LwB. Apparently, the opportunity to speak out about her experiences and concerns through the interview led to a critical reflection on the way the undergraduate program she was taking was structured. We may think that this part of her account highlights Brockmeier's (2000) statement concerning the fact that we organize our memories, thoughts, and feelings in many forms of oral and written discourse.

Overall, as pointed out by the teachers in their answers, the factors that most contributed to their professional develop seem to be four. The opportunity to experience professional practice articulated with theory is somehow present in the three teachers' narratives, although not explicit in the accounts of all of them. Another point that is often identified in their discourse is the shared work with their colleagues, which clearly plays an important role to foster a professional culture and reinforces the idea of a community of practice. A third factor that is brought up by the three teachers is the 
freedom the LwB provides, allowing them to make informed decisions and deliberations. This last factor, we dare to say, seems to give evidence to the inseparability of their professional and their personal development, as pointed out by Novoa. All the three teachers at some point reveal a gain in self-confidence and in their autonomy throughout the period they acted in the program, which obviously is not limited, as one may think, to the professional dimension. Moreover, we can verify their personal growth through the development of their pedagogical tact in dealing with different students (from the ones they were expecting, or from those they were used to, or even from themselves) and different classroom settings, as in having people from various areas of knowledge in their classroom.

\section{Conclusion}

This paper aimed at observing the formative role of the $\mathrm{LwB}$ program in the development of three pre-service language teachers at a high-ranked federal free-tuition university in southern Brazil. More specifically, the purpose was to shed light on the personal and professional development of these teachers according to Nóvoa's (2009) perspective.

In answering the question posed, four topics showed to be noteworthy: the articulation between theory and practice that the program enables; the shared work with colleagues which fosters their professional growth; the freedom to deliberate and make informed decisions; and, finally, the inseparability of the professional and personal development, revealed through a growth in confidence and autonomy, i.e., the acquired readiness with which they exercise their profession.

As it is pointed out by Welp (2016, p. 304), "programs such as Languages Without Borders (...) show the importance of classroom experience since initial teacher education" 15 , because they allow pre-service teachers to share experiences anchored in discussions sustained by the articulation of theory and practice. As Nóvoa (2009) puts it, teachers should prepare themselves for self-reflection, and self-analysis seeing that it is impossible to separate personal and professional dimensions. These accounts were themselves an opportunity of such proposals.

\footnotetext{
${ }^{15}$ Original: "Programas como o Idiomas sem Fronteiras ou o PIBID evidenciam a importância da experiência docente em sala de aula desde a formação inicial de professores."
} 
Only by having the freedom teachers claimed having found in the program it is viable to create a culture that fosters visibility, confidence, and public participation in debates about education, as opposed to what Nóvoa argues to be the commonplace. Through practices that range from the elaboration of class plans to the creation of courses, teachers become co-authors of educational public policies. These aspects give evidence to feelings of belonging and responsibility which are indispensable when taking on teaching with all it implies and allow pre-service teachers to give new directions to the profession.

\section{References}

BROCKMEIER, J. Autobiographical Time, Narrative Inquiry, 10(1), 2000, p. 51-73. https://doi.org/10.1075/ni.10.1.03bro

CLANDININ, D. Jean; Pushor, Debbie; ORR, Anne Murray. Navigating sites for narrative inquiry. Journal of Teacher Education, Vol. 58, No. 1, January/February 2007,p. 21-35.

https://doi.org/10.1177/0022487106296218

CONNELLY, F. Michael \& CLANDININ, D. Jean. Narrative inquiry. In: GREEN, Judith L., CAMILLI, Gregory, ELMORE, Patricia B., SKUKAUSKAITI, Audra, GRACE, Elizabeth (Eds.). Handbook of complementary methods in education research. London: Routledge, 2006, p. 477-487.

DEWEY, J.. Experience and education. New York: Collier Books, 1938.

ELLIOTT, Jane. Narrative and new developments in the social sciences In: Using Narrative in Social Research. London: SAGE Publications Ltd., 2011, p. 2-16.

FLORES, José Ignacio R. Introdución: algunas reflexiones para abrir caminos. In: FLORES, José ignácio R., MENDÉZ, Analía E. L., MEJÍAS, Esher P. (Coords.) Profesorado, escuela y diversidad: la realidad educativa desde una mirada narrativa. Málaga. Archidona, 2014, p. 15 - 23.

FREIRE, Paulo. Política e educação: ensaios. Coleção Questões de nossa Época, v. 23. São Paulo: Cortez, 2001.

PINNEGAR, Stefinee \& DAYNES, J. Gary. Locating narrative inquiry historically: thematics in the turn to narrative. In: CLANDININ, D. Jean (Ed.). Handbook of narrative inquiry: mapping a methodology. Thousand Oaks: SAGE Publications, Inc., 2012, p. 3-34.

NÓVOA, Antônio. Para uma formação de professores construída dentro da profissão. In: Professores: imagem do futuro presente. Lisboa: EDUCA, 2009, (p. 26-47).

\section{O regresso dos professores . Conferência Desenvolvimento}

Profissional de Professores para a Qualidade e para a Equidade da Aprendizagem ao Longo da Vida. Lisboa, 2007. 
SANCHO, Juana M, \& HERNANDEZ, Fernando H. Developing autobiographical accounts as a starting point in research. European Educational Research Journal. Vol. 12, n. 3, 2013, p. $342-353$.

https://doi.org/10.2304/eerj.2013.12.3.342

WENGER-TRAYNER, E \& B. Communities of practice: a brief introduction. http://wenger-trayner.com/introduction-to-communities-of-practicel. 2015. 